\title{
Transformation and allelic replacement in Francisella spp.
}

\author{
Lawrence S. D. Anthony, ${ }^{1}$ Maozhi Gu, ${ }^{1,2}$ Siobhán C. Cowley, ${ }^{1,2}$ Wendy W. S. Leung ${ }^{1}$ and \\ FraNCIS E. NANO ${ }^{1,2,3 *}$ \\ ${ }^{1}$ Department of Biochemistry and Microbiology, University of Victoria, Victoria, British Columbia V8W 3P6, Canada \\ ${ }^{2}$ Canadian Bacterial Disease Network \\ ${ }^{3}$ Health and Human Services, National Institutes of Health, Laboratory of Microbial Structure and Function, \\ Rocky Mountain Laboratories, Hamilton, MT 59840, USA
}

(Received 8 April 1991; revised 27 August 1991; accepted 5 September 1991)

\begin{abstract}
We describe methods for transposon mutagenesis and allelic replacement in the facultative intracellular pathogen Francisella. Recombinant clones were constructed by insertion of partially cut $F$. tularensis or $F$. novicida DNA into pUC19 and then mutagenized with a mini-Tn10-Km transposon. $F$. novicida could be transformed with these plasmids either by a chemical transformation method or by electroporation, whereas $F$. tularensis could be transformed only by electroporation. Transformation of $F$. tularensis by electroporation was enhanced in the absence of the capsule. Southern blot analysis showed that the $\mathrm{Km}^{\mathrm{R}}$ marker was rescued either by integration of the plasmid into the Francisella chromosome or by allelic replacement. Allelic replacement was found to be the mechanism underlying a site-specific mutation affecting FopA, an outer-membrane protein of Francisella. $F$. novicida could also be transformed with chromosomal DNA carrying the $\mathrm{Km}^{\mathrm{R}}$ marker and the transformation frequency obtained using chromosomal DNA was generally greater than that obtained using plasmid DNA. $F$. novicida was also transformed by an IncQ plasmid containing an $F$. novicida DNA insert, which replicated autonomously in this host.
\end{abstract}

\section{Introduction}

Francisella tularensis, the causative agent of tularemia, is an encapsulated Gram-negative cocco-bacillus that is a facultative intracellular pathogen (Bell, 1981 ; Eigelsbach and McGann, 1984). F. tularensis infection has been used in several studies as a model of T-cell-mediated immunity (Allen 1961; Anthony \& Kongshavn, 1987; Eigelsbach et al., 1975; Kostiala et al., 1975). The bacterium grows inside macrophages, and is eliminated from surviving animals by a mechanism which involves gamma interferon (Anthony et al., 1989) and, presumably, activated macrophages. Although the immunological aspects of infection have received considerable attention, there has been little study of the bacterial factors that contribute to virulence.

Francisella novicida is a species that is closely related to $F$. tularensis (Larson et al., 1955), but until recently it had been isolated only once from the environment. Both species cause identical diseases in experimental animals. $F$. novicida differs from $F$. tularensis in its ability to

This paper is dedicated to the memory of Bengtåke Jaurin. ferment sucrose, in its expression of agglutinating surface antigen (Owen et al., 1964) (probably capsule) and in its apparent lack of infectivity for humans, as surmised from the lack of infection in laboratory workers over a 30 year period. However, it was found recently that $F$. novicida-like strains have infected a small number of severely immunocompromised individuals (Wenger $e t$ al., 1989; Hollis et al., 1989). The geographical distribution of the infected patients indicates that $F$. novicidalike strains are widely distributed in nature.

In order to facilitate a genetic approach to the study of virulence in Francisella we analysed methods for introducing exogenous DNA, especially genetically engineered DNA from Escherichia coli, into Francisella. Tyeryar \& Lawton $(1969,1970)$ showed that $F$. novicida can be transformed with chromosomal DNA from both $F$. novicida and $F$. tularensis. In this study, we describe the parameters necessary for the introduction of exogenous DNA into $F$. novicida and the construction of mutants by insertional inactivation of genes. Moreover, we describe a procedure for the transformation of $F$. tularensis, which requires different conditions from that for $F$. novicida. 
Table 1. Bacterial strains and plasmids

\begin{tabular}{|c|c|c|}
\hline Strain/plasmid & Relevant characteristics & Source/reference \\
\hline F. tularensis LVS & Live vaccine strain & Eigelsbach \& Downs, (1961); Salk Institute \\
\hline F. tularensis LVSR & Capsule-negative variant of LVS & Sandström et al. (1988); G. Sandström \\
\hline F. tularensis $504-3$ & $z a a:: \operatorname{Tn} 10-\mathrm{Km}$ & This study \\
\hline F. novicida U112 & Wild-type strain & Larson et al. (1955); ATCC \\
\hline F. novicida $68-1$ & $z b b: \operatorname{Tn} 10-\mathrm{Km}$ & \\
\hline F. novicida $68-11$ & fop $A-1:: \operatorname{Tn} 10-\mathrm{Km}$ & This study \\
\hline F. novicida $68-17$ & fop $A-2:: \mathrm{Tn} 10-\mathrm{Km}$ & \\
\hline E. coli DH5 $\alpha$ & $\begin{array}{l}\mathrm{F}^{-} \Phi 80 \text { lac } Z \Delta \mathrm{M} 15 \text { end } A 1 \text { recAl hsdRI7 supE44 thil } \\
\text { gyrA96 relAl } \Delta(\text { lac } Z Y A-\arg F) \mathrm{U} 169\end{array}$ & Bethesda Research Laboratories \\
\hline pUC19 & $A p^{R}$ cloning vector & Vieira \& Messing (1982) \\
\hline pRL497 & $\mathrm{Km}^{\mathrm{R}}$, IncQ & Elhai \& Wolk (1988) \\
\hline pDSK 519 & $\mathrm{Km}^{\mathrm{R}}$, IncQ & Keen et al. (1988) \\
\hline pLA68 & pUC19:: Sau3AI $(6.5 \mathrm{~kb}) F$. novicida, clone of fop $A$. & \\
\hline pLA68-1 & pLA68::Tn $10-\mathrm{Km}$ & \\
\hline pLA68-11 & pLA68::Tn $10-\mathrm{Km}$ & \\
\hline pLA68-17 & pLA68::Tn10-Km & This study \\
\hline pFEN504 & pUC19:: Sau3AI $(11 \mathrm{~kb}) F$. tularensis, LVS DNA & \\
\hline pFEN504-3 & pFEN504::Tn10-Km & \\
\hline pFEN520 & pRL497::F. novicida Sau3AI $(4.9 \mathrm{~kb})$ DNA & \\
\hline
\end{tabular}

\section{Methods}

Bacterial strains. Bacterial strains and plasmids are listed in Table 1. Francisella strains were grown routinely in Chamberlain's defined medium (Chamberlain, 1965) or tryptic soy broth containing $0.1 \%$ cysteine hydrochloride (TSB-C). Cystine-heart agar (Difco) supplemented with $5 \%$ defibrinated horse blood (CHA-H) and an appropriate antibiotic was used as the solid growth medium. Each lot of blood was tested for its ability to support growth of $F$. tularensis. E. coli strains were grown in LB (Sambrook et al., 1989) medium. Sodium ampicillin $\left(250 \mu \mathrm{g} \mathrm{ml}^{-1}\right)$ and kanamycin sulphate $\left(\mathrm{Km}, 30 \mu \mathrm{g} \mathrm{ml}^{-1}\right)$ were used for selection of the appropriate plasmids and transposons in E. coli. Biosafety procedures followed the guidelines of the two different host institutions; in general, biosafety level II containment and procedures were used.

DNA methylation analysis. DNA methylation studies were done by the Cancer Research Center (Columbia, MO, USA) using reverse phase HPLC. This analysis revealed no methylated deoxyribonucleosides, and integration of the nucleoside peaks showed that the $\mathrm{G}+\mathrm{C}$ mol $\%$ of the $F$. tularensis DNA was $33 \%$.

Western immunoblotting procedure. SDS-PAGE was done by the method of Dreyfuss et al. (1984). Proteins separated by SDS-PAGE were transferred to Nitroscreen West (Dupont) membrane using a discontinuous buffer system with a semi-dry immunoblotting apparatus (LKB) according to the manufacturer's instructions. The anti- $F$. novicida serum used to develop the immunoblots was raised in New Zealand White rabbits as described previously for $F$. tularensis (Nano, 1988). Blots were treated with ${ }^{125}$ I-labelled protein A (Dupont) for autoradiography.

Recombinant DNA procedures. Standard recombinant techniques (Sambrook et al., 1989) were used throughout. Clone banks were generated by ligating $F$. novicida chromosomal DNA, partially cut with Sau3AI, into the BamHI site of cloning vectors. Transposon mutagenesis was done using $\lambda 1105$ to deliver a mini- $\mathrm{Tn} 10-\mathrm{Km}$ element (Way et al., 1984) into E. coli strains harbouring recombinant plasmids. Standard Southern blotting techniques (Sambrook et al., 1989) were used to transfer DNA onto GeneScreen Plus (Dupont). DNA was labelled by random priming (Dupont kit) and separated from unincorporated ${ }^{32} \mathrm{P}$-labelled deoxynucleotides on NENSORB columns (Dupont).

Transformation protocol. $F$. novidica were grown in Chamberlain's medium to a density of $1-3 \times 10^{9}$ c.f.u. $\mathrm{ml}^{-1}$. Cells were harvested from a $10 \mathrm{ml}$ culture by centrifugation at $12000 \mathrm{~g}$ and resuspended in $1 \mathrm{ml}$ of transformation buffer (Tyeryar \& Lawton, 1970) modified to exclude $\mathrm{Mg}^{2+}$ and $\mathrm{Mn}^{2+}$ salts; $300 \mu \mathrm{l}$ of this concentrated cell suspension was added to a $1.5 \times 15 \mathrm{~cm}$ glass culture tube along with $5 \mu 1$ of DNA. Plasmid DNA was isolated by gel-filtration using Sephacryl S-1000 (Pharmacia). Chromosomal DNA was isolated as described by Wilson (1987). The mixture was incubated at $37^{\circ} \mathrm{C}$ for $1 \mathrm{~h}$ with shaking at 100 r.p.m. Chamberlain's medium $(2 \mathrm{ml})$ was added and the shaking frequency increased to 250 r.p.m. After a $2 \mathrm{~h}$ expression period, appropriate dilutions were plated on $\mathrm{CHA}-\mathrm{H}$ containing $\mathrm{Km}\left(10 \mu \mathrm{g} \mathrm{ml}^{-1}\right)$ and incubated at $37^{\circ} \mathrm{C}$ for $24-48 \mathrm{~h}$.

Electroporation protocol. F. novicida and $F$. tularensis LVS were grown in TSB-C. Cells from $40 \mathrm{ml}$ of early to mid-exponential phase cultures were centrifuged at $12000 \mathrm{~g}$ for $10 \mathrm{~min}$ and resuspended in $10 \mathrm{ml}$ $500 \mathrm{~mm}$-sucrose. The cells were washed again and resuspended in $1 \mathrm{ml}$ of sucrose in a microfuge tube. After a 4 min centrifugation in a microfuge the cells were resuspended in $120 \mu$ l of sucrose and kept on ice; $40 \mu \mathrm{l}$ of this cell suspension were then added to an electroporation cuvette $(0.1 \mathrm{~cm}$ gap) and $2 \mu \mathrm{l}$ of DNA solution was added immediately before electroporation. Electroporation was done using a Gene Pulser apparatus (Bio-Rad) set at various voltages, with a $25 \mu \mathrm{F}$ capacitance setting. A pulse control unit was used with the Gene Pulser with the resistance level set at $400 \Omega$. The average time constants for the $7 \cdot 5,15$ and $25 \mathrm{kV}$ pulses were $7.5 \mathrm{~ms}, 5.9 \mathrm{~ms}$ and $0.8 \mathrm{~ms}$, respectively. In some experiments, $F$. tularensis was treated prior to washing in sucrose with the detergent $N$-hexadecyl- $N, N$-dimethyl-3-ammonio-1-propanesulphonate (HDAP), which was added directly to the Francisella culture to a final concentration of $2 \%$. Within $90 \mathrm{~s}$ of electroporation $1 \mathrm{ml}$ of TSB-C was added and the cells were transferred to $1.5 \times 15 \mathrm{~cm}$ glass culture tubes. The cultures were shaken $\left(250\right.$ r.p.m.) at $37^{\circ} \mathrm{C}$. $F$. novicida was grown for $2 \mathrm{~h}$ before plating on $\mathrm{CHA}-\mathrm{H}$ containing $\mathrm{Km}$ 
$\left(10 \mu \mathrm{g} \mathrm{ml}^{-1}\right)$, while $F$. tularensis was grown for $6 \mathrm{~h}$ before plating on CHA-H containing $\mathrm{Km}(5 \mu \mathrm{g} \mathrm{ml}-1)$. Under these growth conditions, the generation time for $F$. novicida was approximately $1 \mathrm{~h}$ while that of $F$. tularensis was approximately $3 \mathrm{~h}$ as determined by measuring turbidity with a Klett-Summerson colorimeter. Since the pulses frequently generated sparks, all electroporation experiments were done in type II biosafety cabinets.

\section{Results and Discussion}

\section{Lack of restriction barrier}

Analysis of $F$. tularensis LVS DNA indicated that it was not methylated. This suggested that there was no conventional DNA restriction/modification system in this strain. Previously published results (Tyeryar \& Lawton, 1970) indicated that transformation of $F$. novicida is equally efficient whether the DNA is derived from $F$. tularensis LVS or from $F$. novicida. Moreover, transformation of $F$. novicida with a broad-host-range plasmid (see below) isolated from $F$. novicida or $E$. coli occurred at the same frequency. Taken together, these observations suggest that there is no restriction system in these two strains.

Transformation of $F$. novicida using recombinant plasmids and integrative rescue

Attempts were made to introduce non-Francisella DNA into $F$. novicida using autonomously replicating broadhost-range plasmids, or by rescue of antibiotic resistance markers by transposition. These attempts failed to yield any colonies (data not shown). Since transformation of $F$. novicida using its own chromosomal DNA was easily demonstrated, it was hypothesized that Francisella sequences are necessary for transformation. In order to include $F$. novicida sequences in the transforming DNA we constructed recombinants consisting of $F$. novicida DNA partially cut with Sau $3 \mathrm{AI}$ inserted into the BamHI site of pUC19. We then used $\lambda 1105$ to transpose mini$\mathrm{Tn} 10-\mathrm{Km}$ into the plasmid insert to provide a selectable marker.

One recombinant clone, pLA68, was chosen for detailed analysis (Figs 1 and $2 a$ ). This clone encodes a protein analogous to the FopA protein of $F$.tularensis, which is an outer-membrane protein and a major immunogen (Bevanger et al., 1988; Nano, 1988). FopA migrates as a $43 \mathrm{kDa}$ doublet on PAGE when heated to $95^{\circ} \mathrm{C}$ or as a $34 \mathrm{kDa}$ single band when solubilized at lower temperatures. Plasmid pLA68 was mutagenized by insertion of mini- $\mathrm{Tn} 10-\mathrm{Km}$, and $\mathrm{Km}$-resistant clones were examined for expression of FopA. Western blot analysis revealed that $E$. coli harbouring pLA68-1 retained expression of FopA, whereas $E$. coli harbouring

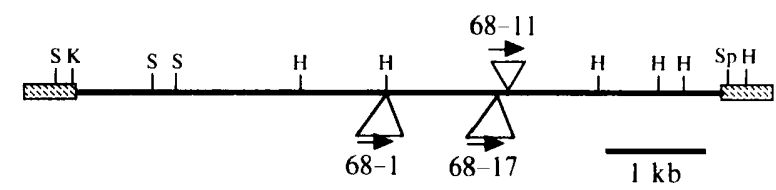

Fig. 1. Restriction map of pLA68. The solid black line indicates the $F$. novicida DNA insert. The stippled boxes represent the polylinker region of pUC19 (not drawn to scale). Triangles indicate the locations of mini-Tn10-Km insertions in plasmids pLA68-1, pLA68-11 and pLA68-17. The third HindIII site from the right may be located $350 \mathrm{bp}$ to the left. The mini- $\mathrm{Tn} 10-\mathrm{Km}$ is $1675 \mathrm{bp}$ and has a HindIII site at bp 1014 (from the left). Arrows indicate the direction of transcription of the $\mathrm{Km}^{\mathrm{R}}$ gene. Abbreviations for restriction enzymes: H, HindIII; $\mathrm{K}, \mathrm{KpnI} ; \mathrm{S}$, SstI $; \mathrm{Sp}$, SphI.

pLA68-11 or pLA68-17 did not (Fig. $2 a$ ). Plasmid DNA from the pLA68:: $\operatorname{Tn} 10-\mathrm{Km}$ derivatives were used to transform $F$. novicida selecting for $\mathrm{Km}$ resistance. Two distinct phenotypes were observed (Fig. $2 b$ ). $F$. novicida 68-17, which resulted from transformation with pLA6817 (no expression of FopA in E. coli) did not produce FopA. However, a new immunoreactive peptide of $36 \mathrm{kDa}$ was detected. This could be a truncated derivative of FopA resulting from the insertion of the mini-transposon. Transformation with plasmid pLA68-1 (expression of FopA in E. coli) or plasmid pLA68-11 (no expression of FopA in $E$. coli) yielded $F$. novicida strains that still expressed FopA.

The results of Southern blot analysis of genomic DNA of the $F$. novicida transformants provided possible explanations for the Western immunoblot results. Fig. $3(b)$ (lane 2) shows that when a Southern blot was probed with ${ }^{32}$ P-labelled pUC19 DNA, a hybridizing band was found in the $F$. novicida 68-11B DNA. This indicates that pUC19 sequences, together with the transposon and some or all of the $F$. novicida recombinant DNA, integrated into the $F$. novicida chromosome by a Campbell-type recombination event. Such an event should not diminish expression of FopA since an intact copy of the fop $A$ gene would be preserved in addition to the transposon-mutagenized copy. In pLA68-11 the mini-Tn $10-\mathrm{Km}$ insertion has caused the replacement of a $2.1 \mathrm{~kb} H$ HindIII fragment by two fragments of 2.2 and $1.6 \mathrm{~kb}$ (the $1.7 \mathrm{~kb}$ mini-Tn $10-\mathrm{Km}$ carries a HindIII site). The sizes of the two bands containing sequences which hybridize with pNK862 (a pBR322-based plasmid carrying the mini-Tn $10-\mathrm{Km}$ element) in $F$. novicida $68-11$ chromosomal DNA are the same size as in pLA68-11 plasmid DNA (lanes 2 and 6). This is consistent with the plasmid having integrated into the chromosome. Similarly, the fact that the transposon but not the plasmid sequences of pLA68-17 integrated in $F$. novicida $68-17$ (lane 1, Fig. $3 b, c$ ) suggests that gene replacement caused loss of expression of FopA. This is consistent with the 
(a)

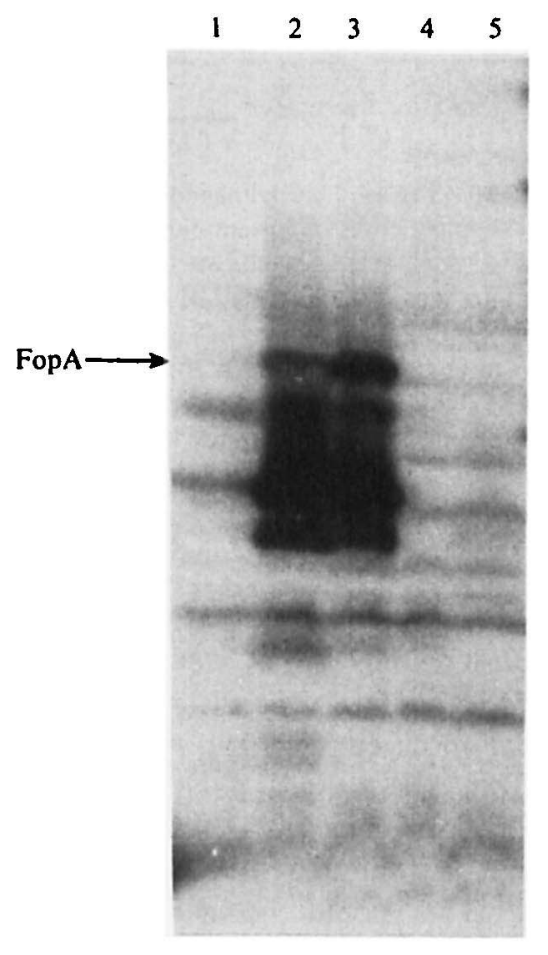

(b)

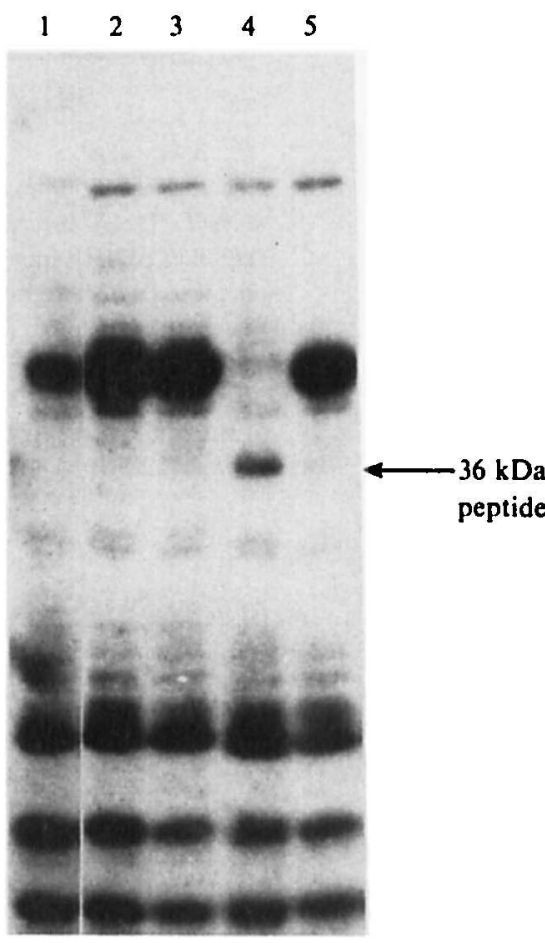

Fig. 2. Western immunoblot of E. coli recombinants and $F$. novicida mutants. Blots were reacted with anti$F$. novicida antiserum. (a) Immunoblot of extracts of E. coli strains harbouring recombinant plasmids containing $F$. novicida insert DNA, those recombinants mutagenized with mini-Tn $10-\mathrm{Km}$ and an E. coli control. Lane 1, DH $5 \alpha$; lane 2, DH $5 \alpha(\mathrm{pLA} 68)$; lane 3 , DH5 $\alpha$ (pLA68-1); lane 4, DH5 $\alpha$ (pLA68-17); lane 5, DH5 $\alpha$ (pLA68-11). The arrow at the left indicates the mobility of the slowest-migrating FopA band. (b) Immunoblot of extracts of $F$. novicida strains that had been transformed with recombinant plasmids containing transposon inserts. Lane $1, F$. novicida; lane $2, F$. novicida $68-1$; lane $3, F$. novicida $68-11$ B; lane 4 , $F$. novicida $68-17$; lane $5, F$. novicida with mini- $\operatorname{Tn} 10$ $\mathrm{Km}$ inserted in another region of the chromosome. The arrow at the right points to a $36 \mathrm{kDa}$ peptide thought to be a truncated derivative of FopA. (a)

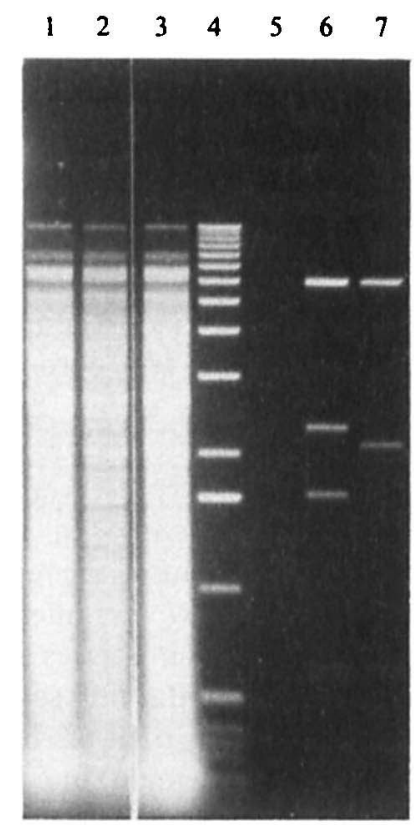

(b)

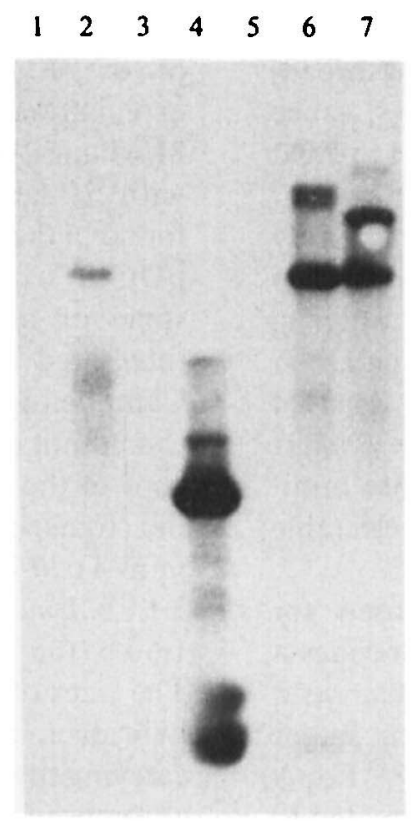

(c)

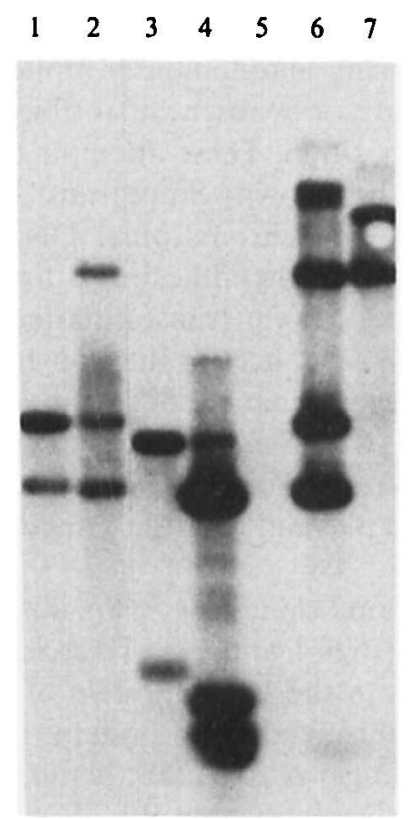

Fig. 3. Southern blot analysis of transformants. Lanes 1, 2 and 3, F. novicida strains 68-17, 68-11B and 68-1; lane 4, 1 kb size standard; lane 5, blank; lane 6, plasmid pLA68-11; lane 7, plasmid pLA68. (a) Agarose gel of HindIII-cut chromosomal DNA from various transformant strains of $F$. novicida and HindIII-cut plasmid DNA. (b) Southern blot of the gel shown in (a) probed with ${ }^{32} \mathrm{P}$-labelled pUC19. A $350 \mathrm{bp}$ fragment which includes $34 \mathrm{bp}$ of the pUC19 sequence appears as a weakly hybridizing band at the bottom of the blots in lanes 6 and 7. This fragment is also present in lane 2, but is too weak to be seen in this reproduction. $(c)$ The same Southern blot as in (b), reacted instead with pNK862, a pBR322-derived plasmid that contains the mini-Tn $10-\mathrm{Km}$ element. Wild-type $F$. novicida DNA did not react with either probe (data not shown). 
Table 2. Transformation of $F$. novicida

The values represent means of three experiments; standard deviations are indicated in parentheses.

\begin{tabular}{lcc}
\hline \hline & \multicolumn{2}{c}{ Transformants per $\mu \mathrm{g} \mathrm{DNA}$} \\
\cline { 2 - 3 } Genetic locus & Plasmid DNA & Chromosomal DNA \\
\hline $68-1$ & $46(0)$ & $2 \cdot 1 \times 10^{6}\left(1 \cdot 2 \times 10^{6}\right)$ \\
$68-11 \mathrm{~B}$ & $6.1 \times 10^{5}\left(2 \cdot 1 \times 10^{5}\right)$ & $2.6 \times 10^{6}\left(1.1 \times 10^{6}\right)$ \\
$68-17$ & $61(48)$ & $2.2 \times 10^{6}\left(4.1 \times 10^{5}\right)$ \\
\hline \hline
\end{tabular}

appearance of the $36 \mathrm{kDa}$ immunoreactive peptide in the Western blot. We found no evidence of extrachromosomal replication in $F$. novicida of the pUC19-derived recombinant plasmids.

\section{Factors affecting transformation of $F$. novicida}

Wide variations in the frequency of transformation were found when different plasmid constructs were used to transform $F$. novicida. Transformation with plasmids derived from pLA68 by mini- $\mathrm{Tn} 10-\mathrm{Km}$ insertion illustrate this variation (Table 2). One plasmid, pLA68-11, gave high frequency transformation $\left(6 \times 10^{5}\right.$ transformants $\mu \mathrm{g}^{-1}$ ) whereas two other plasmids, pLA68-1 and pLA68-17 yielded about 10000-fold fewer transformants. Given the fact that the transposon inserts in pLA68-11 and pLA68-17 are approximately 300 bp apart (Fig. 1), it is particularly surprising that the plasmids transform $F$. novicida at such markedly different frequencies. The location of the transposon seems to be a major determinant in the transformation efficiency.

To examine other factors that might affect transformation efficiency, we isolated chromosomal DNA from the $F$. novicida strains $68-1,68-11$ and $68-17$. When these chromosomal DNA preparations were used to transform $F$. novicida each yielded approximately the same number of $\mathrm{Km}$-resistant colonies (Table 2), and the frequency of the transformation per $\mu \mathrm{g}$ DNA was similar to that of plasmid pLA68-11. Actually, the chromosomal DNA gave a much higher transformation frequency than pLA68-11 considering that a much smaller proportion of the chromosomal DNA contains the $\mathrm{Km}^{\mathrm{R}}$ locus. Apparently, the length of DNA also influences the efficiency greatly, since transformation using plasmid pLA68-11 DNA that had been linearized by cutting with $S p h \mathrm{I}$, which cuts only in the vector DNA, abolished transformation (data not shown). Lastly, chromosomal DNA was found to transform at a higher frequency (approximately 100 -fold) when sheared fragments of $20-40 \mathrm{~kb}$ were used, in comparison with high-molecular-mass DNA (data not shown).

Several parameters that might have affected transformation competence were investigated. $F$. novicida transformed equally well after incubation with DNA in the transformation buffer for $5 \mathrm{~min}$ (followed by addition of DNAase) or for $1 \mathrm{~h}$. Heat shock, which enhances transformation of $E$. coli (Mandel \& Higa, 1970) did not enhance transformation of $F$. novicida (data not shown).

\section{Transformations with broad-host-range plasmids}

Attempts to introduce broad-host-range plasmids into $F$. novicida and $F$. tularensis by conjugation or transformation failed. However, when IncQ plasmids containing Francisella DNA inserts were used, transformants could be recovered.

Several derivatives of pRL497 or pDSK 519 carrying Sau3AI fragments from $F$. novicida cloned into the BamHI site were constructed. Nine recombinant plasmids were isolated with the capacity to transform $F$. novicida. The sizes of the insertions in these clones ranged from $0 \cdot 5-5 \cdot 0 \mathrm{~kb}$. The transformation frequency obtained using these plasmids was less than 10 transformants per $\mu \mathrm{g}$ DNA. Analysis of genomic DNA of the transformants suggested that the plasmid DNA was extrachromosomal and was present in multiple copies (data not shown). Both $E$. coli and $F$. novicida could be transformed with DNA isolated from $F$. novicida strains carrying the pRL497 recombinants, which supports the notion that the plasmids in $F$. novicida replicated autonomously.

The results reported here concerning transformation of $F$. novicida suggest that Francisella DNA is needed for efficient transformation to occur. In this regard, $F$. novicida is similar to Haemophilis, Neisseria and Campylobacter (Goodman \& Scocca, 1988; Sisco \& Smith, 1979; Wang \& Taylor, 1990). In the case of Haemophilis and Neisseria, specific DNA uptake sequences are known to be required for transformation. However, transformation of $F$. novicida seems to be different in that it requires the presence of cations, whereas transformation of these other bacteria does not. Attempts to demonstrate Francisella-specific uptake sequences by competitively inhibiting transformation with Francisella DNA were unsuccessful. However, we have not ruled out the role of uptake sequences in a complicated transformation process.

\section{Electroporation of $F$. tularensis}

Attempts to transform $F$. tularensis with pUC19 recombinants containing $F$. tularensis DNA and marked with mini- $\mathrm{Tn} 10-\mathrm{Km}$ using the transformation protocol for $F$. 


\section{Table 3. Electroporation of Francisella}

The values represent the results from individual experiments. Besides the variation in field strengh all the conditions are as described in Methods. The numbers in parentheses represent the percentage of each culture surviving the electroporation pulse.

\begin{tabular}{lccc}
\hline \hline \multirow{2}{*}{$\begin{array}{l}\text { Field } \\
\text { strength }\end{array}$} & \multicolumn{3}{c}{ Transformants per $\mu \mathrm{g} \mathrm{DNA}^{*}$} \\
\cline { 2 - 4 } & $7.5 \mathrm{kV} \mathrm{cm}^{-1}$ & $15 \mathrm{kV} \mathrm{cm}^{-1}$ & $25 \mathrm{kV} \mathrm{cm}^{-1}$ \\
\hline F. tularensis LVS & 128 & 2259 & 41 \\
& $20(82 \%)$ & $149(39 \%)$ & $46(3 \%)$ \\
F. tularensis LVS & 3451 & 2015 & 231 \\
+ HDAP & $226(125 \%)$ & $82(16 \%)$ & $5(106 \%)$ \\
F. tularensis LVSR & 431 & 6052 & 1594 \\
& $5(83 \%)$ & $303(57 \%)$ & $4657(60 \%)$ \\
F. novicida & $<1 \dagger$ & $<1 \dagger$ & $<1 \dagger$ \\
\hline \hline
\end{tabular}

* The DNA used to transform $F$. novicida was pLA68-11 and for $F$. tularensis pFEN504-3. In the absence of DNA no kanamycin-resistant $F$. tularensis colonies were found.

$\dagger$ Rare transformants; these transformants were verified by Southern blot analysis.

novicida were unsuccessful. However, both $F$. tularensis and $F$. novicida could be transformed with plasmid DNA by high-field-strength electroporation (Table 3), although transformation of $F$. novicida was inefficient. As with transformation of $F$. novicida, transformation frequency of $F$. tularensis by electroporation was highly dependent upon the plasmid DNA.

The effect of the capsule of $F$. tularensis on electroporation was investigated by removing the capsule by detergent treatment and by using a capsule-deficient strain. The detergent HDAP was found to enhance the electroporation efficiency at the lower electric field strengths without diminishing the viability of $F$.tularensis cultures (Table 3). Furthermore, the capsule-deficient strain of $F$. tularensis gave higher transformation frequencies than the encapsulated strain, except at the lower field strength. These results indicate that the capsule of $F$. tularensis does indeed constitute a significant barrier to the efficiency of transformation by electroporation. There was considerable variation in both the transformation frequency and the survival rate of the cultures undergoing electroporation. We attribute these differences to variations in the conductance of the solutions in the cuvettes resulting from leakage of ions from the very fragile Francisella cells.

In this work we have demonstrated that broad-hostrange plasmids and chimeric narrow host range plasmids carrying Francisella chromosomal DNA fragments and an insert of mini-Tn $10-\mathrm{Km}$ can be transformed into $F$. novicida and $F$. tularensis. The transposon mutagenesis scheme described here demonstrates how mutants lacking specific proteins can be isolated. This should facilitate an evaluation of the role of surface proteins and other potential virulence factors in the pathogenicity of Francisella infections. Although the transformation frequency of the broad-host-range plasmid recombinants was low, the frequency was sufficient for the construction of merodiploid strains. Such strains can be used to study gene expression or genetic complementation of genes involved in the control of virulence.

This work was supported by grants to F.E.N. from the British Columbia Health Care Research Foundation and the Natural Sciences and Engineering Research Council of Canada. L.S.D.A. is supported by the Medical Research Council of Canada. W.W.S. L. is supported by a Summer Studentship from the Province of British Columbia. The authors would like to thank $\operatorname{Dr} R$. Roberts for testing for the presence of restriction enzymes, and Dr C. Rickey for supplying prototype $0 \cdot 1 \mathrm{~cm}$ gapped cuvettes.

\section{References}

ALLEN, W. P. (1961). Immunity against tularemia: passive protection of mice by transfer of immune tissues. Journal of Experimental Medicine 115, 411-420.

Anthony, L. S. D. \& Kongshavn, P. A. L. (1987). Experimental murine tularemia caused by Francisella tularensis, live vaccine strain: a model of acquired cellular resistance. Microbial Pathogenesis 2, 3-14.

Anthony, L. S. D., Ghadirian, E., Nestel, F. P. \& Kongshavn, P. A. L. (1989). The requirement for gamma interferon in resistance of mice to experimental tularemia. Microbial Pathogenesis 7, 421428.

BELL, J. F. (1981). Francisella. In Handbuch der Bakteriellen Infektionen bei Tieren, pp 172-256. Edited by H. Blobel \& T. Schliber. Jena: Veb Gustav Fisher Verlag.

Bevanger, L., Maeland, L. A. \& Naess, A. T. (1988). Agglutinins and antibodies to Francisella tularensis outer membrane antigens in the early diagnosis of disease during an outbreak of tularemia. Journal of Clinical Microbiology 26, 433-437.

Chamberlain, R. E. (1965). Evaluation of live tularemia vaccine prepared in a chemically defined medium. Applied Microbiology 13, 232-235.

Dreyfuss, G., AdAM, S. A. \& ChoI, Y. D. (1984). Physical change in cytoplasmic messenger ribonucleoproteins in cells treated with inhibitors of mRNA transcription. Molecular and Cellular Biology 4, 415-423.

Eigelsbach, H. T. \& Downs, C. M. (1961). Prophylactic effectiveness of live and killed tularemia vaccines. I. Production of vaccine and evaluation in the white mouse and guinea pig. Journal of Immunology 87, 415-425.

Eigelsbach, H. T., Hunter, D. H., Janssen, W. A., Dangerfield, H. G. \& Rabinowitz, S. G. (1975). Murine model for study of cellmediated immunity: protection against death from fully virulent Francisella tularensis infection. Infection and Immunity6 12, 999-1005.

Eigelsbach, H. T. \& MCGaNN, V. G. (1984) Francisella. In Bergey's Manual of Systematic Bacteriology, vol. 1, pp. 394-399. Edited by W. R. Krieg \& J. G. Holt. Baltimore: Williams \& Wilkins.

Elhai, J. \& Wolk, C. P. (1988). A versatile class of positive-selection vectors based on the nonviability of palindrome-containing plasmids that allows cloning into long polylinkers. Gene 68, 119-138.

Goodman, S. D. \& SCOCCA, J. J. (1988). Identification and arrangement of the DNA sequence recognized in specific transformation of Neisseria gonorrhoeae. Proceedings of the National Academy of Sciences of the United States of America 85, 6982-6986. 
Hollis, D. G., Weaver, R. E., Steigerwalt, A. G., Wenter, J. D., Moss, C. W. \& BRENNER, D. J. (1989). Francisella philomiragia comb. nov. (formerly Yersinia philomiragia) and Francisella tularensis biogroup novicida (formerly Francisella novicida) associated with human disease. Journal of Clinical Microbiology 27, 1601-1608.

Keen, N. T., Tamaki, S., Kobayashi, D. \& Trollinger, D. (1988). Improved broad-host-range plasmids for DNA cloning in Gramnegative bacteria. Gene 70, 191-197.

Kostiala, A. A. I., MCGregor, D. D. \& Logie, P. S. (1975). Tularemia in the rat. I. The cellular basis of host resistance to infection. Immunology 28, 855-869.

LARSON, C. L., Wicht, W. \& Jellison, W. L. (1955). A new organism resembling $F$. tularensis isolated from water. Public Health Reports 70, 253-258.

MANDEL, M. \& Higa, A. (1970). Calcium-dependent bacteriophage DNA infection. Journal of Molecular Biology 53, 159-162.

NANO, F. E. (1988). Identification of a heat-modifiable protein of Francisella tularensis and molecular cloning of the encoding gene. Microbial Pathogenesis 5, 109-119.

OWen, C. R., BuKer, E. O., Jellison, W. L., LaCkman, D. B. \& Bell, J. F. (1964). Comparative studies of Francisella tularensis and Francisella novicida. Journal of Bacteriology 87, 676-683.

SAMbroOK, J. Fritsch, E. E. \& Maniatis, T. (1989). Molecular Cloning, 2nd edn. Cold Spring Harbor, NY: Cold Spring Harbor Laboratory.

SANDSTRöM, G., LöFgren, S. \& TärNVIK, A. (1988). A capsuledeficient mutant of Francisella tularensis LVS exhibits enhanced sensitivity to killing by serum but diminished sensitivity to killing by polymorphonuclear leukocytes. Infection and Immunity 56, 11941202.

Sisco, K. L. \& SMITH, H. O. (1979). Sequence-specific DNA uptake in Haemophilus transformation. Proceedings of the National Academy of Sciences of the United States of America 76, 972-976.

TYERYAR, F. J. \& LAWTON, W. D. (1969). Transformation of Pasteurella novicida. Journal of Bacteriology 100, 1112-1113.

TYERYAR, F. J. \& LAWTON, W. D. (1970). Factors affecting transformation of Pasteurella novicida. Journal of Bacteriology 104, 1312-1317.

Vieira, J. \& Messing, J. (1982). The pUC plasmids, an M13mp7derived system for insertion mutagenesis and sequencing with synthetic universal primers. Gene 19, 259-268.

Way, J. C., Davis, M. A., Morisato, D., Roberts, D. E. \& Kleckner, N. (1984). New Tn 10 derivatives for transposon mutagenesis and for constructing of lac $Z$ operon fusions by transposition. Gene 32, 369379.

WANG, Y. \& TAYLOR, D. E. (1990). Natural transformation in Campylobacter species. Journal of Bacteriology 172, 949-955.

Wenger, J. D., Hollis, D. G., Weaver, R. E., BaKer, C. N., Brown, G. R., BRENNER, D. J. \& BroOME, C. V. (1989). Infection caused by Francisella philomiragia (formerly Yersinia philomiragia). Annals of Internal Medicine 110, 888-892.

WiLSON, K. (1987). Preparation of genomic DNA from bacteria. In Current Protocols in Molecular Biology, 2.4.1-2.4.5. Edited by F. M. Ausubel, R. Brent, R. E. Kingston, D. D. Moore, J. G. Seidman, J. A. Smith \& K. Struhl. New York: John Wiley. 